\title{
Tandem pseudopericyclic processes in the cyclization of $\alpha$ - diazonitriles to 5-Halo-1,2,3-triazoles. Scope and limitations ${ }^{\dagger}$
}

\author{
Vasiliy A. Bakulev*, Yury Yu. Morzerin, Yuri Yu. Shafran, and Vladimir S. Mokrushin \\ Department of Technology for Organic Synthesis, The Urals State Technical University, 19, \\ Mira str., 620002 Ekaterinburg, Russia \\ E-mail:primavera@ural.org
}

\section{Dedicated to Professor Albert Padwa on the occasion of his $65^{\text {th }}$ birthday}

(received 27 Jun 02; accepted 30 Oct 02; published on the web 07 Nov 02)

\begin{abstract}
A series of $\alpha$-carbonyl diazoacetonitriles has been synthesized and subjected to reaction with hydrogen halides. The scope and limitations of this reaction for preparing 5-halo-1,2,3-triazoles have been determined. The experimental energy of this cyclization is $15-20 \mathrm{Kcal} \mathrm{mol}^{-1}$. A mechanism of this reaction consists of two steps - addition of HHal to $\alpha$-carbonyl diazonitriles via a pseudopericyclic group transfer reaction leads to formation of intermediate $\alpha$-diazohaloimines which in subsequent hetero-electrocyclic reactions afford 5-halo-1,2,3-triazoles. Indeed, the cyclization of $\alpha$-carbonyl diazonitriles is a series of tandem pseudopericyclic processes.
\end{abstract}

Keywords: $\alpha$-Carbonyl diazoacetonitriles, 5-halo-1,2,3-triazoles, tandem pseudopericyclic processes

\section{Introduction}

The reaction of $\alpha$-diazonitriles with hydrogen halides ${ }^{2}$ is a good alternative to the method of synthesis of 5-halo-1,2,3-triazoles based on the Sandmeyer reaction of 5-diazo-1,2,3-triazoles with copper halides in hydrochloric acid. ${ }^{3}$ The 5-halo-1,2,3-triazoles were then used in the synthesis of riboside derivatives that are of great interest as potential biologically active compounds, owing to their similarity to components of nucleic acid metabolism. Despite of the synthetic value of the reaction of diazonitriles with hydrogen halides it has been described for very few examples. ${ }^{4-6}$ The mechanism, scope and limitations of this reaction have not been determined so far. 
To extend these reactions to the synthesis of new 5-halo-1,2,3-triazoles, we have carried out a systematic study of the reactions of a series of diazo-acetonitriles (DAN) having a variety of substituents at the $\alpha$ - position, in various conditions.

\section{Results and Discussion}

The reaction of DAN with hydrogen chloride, hydrogen bromide, or hydrogen iodide in various organic solvents leads to 5-halo-1,2,3-triazoles in very good yields. ${ }^{5}$ We now show that the use of a non-polar solvent leads initially to formation of adducts $\mathbf{2 a - n}$, and $\mathbf{4 a - n}$, of DAN and hydrogen halides in the ratio of 1:2, which could be isolated as solid substances. These adducts have been found to be very sensitive to moisture. The treatment of the adducts $\mathbf{2}-$ and $\mathbf{4 a}-\mathbf{n}$ with water leads easily to the starting DAN. We have found that the adducts 2-, and $4 \mathbf{a}-\mathbf{n}$ could be transformed into the 5-halo-1,2,3-triazoles 3, 5, 6 under heating in the solid state. The structures of the 5-halo-1,2,3-triazoles were confirmed by the synthesis of 5-chloro-1,2,3-triazole-4carboxamide by the Sandmeyer reaction from 5-diazo-1,2,3-triazole-4-carboxamide and copper chloride. $^{3}$

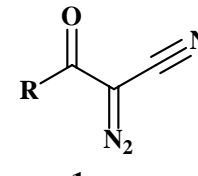

1a-n

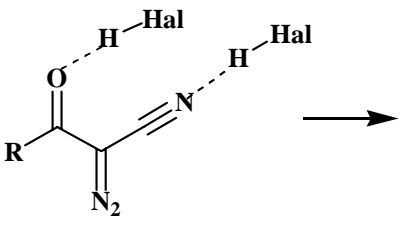

2a-n, 4a-n

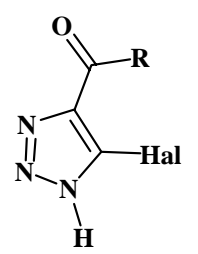

3a-1, 5a-1, 6a-1

$\mathrm{R}=\mathrm{NH}_{2}$ (a); NHMe (b); $\mathrm{NHC}_{6} \mathrm{H}_{11}$-cyclo (c); NHPh (d); $\mathrm{NHC}_{6} \mathrm{H}_{4} \mathrm{OMe}-4$ (e); NHC6H4Me-4 (f); $\mathrm{NHC}_{6} \mathrm{H}_{4} \mathrm{Br}-4$ (g); Oet(h); $\mathrm{Me}(\mathrm{i}) ; \mathrm{Ph}(\mathrm{j}) ; \mathrm{C}_{6} \mathrm{H}_{4} \mathrm{Ome}-4$ (k); $\mathrm{C}_{6} \mathrm{H}_{4} \mathrm{Me}-4$ (l); $\mathrm{CF}_{3}(\mathrm{~m})$; quinolinyl-2 (n) $\mathrm{Hal}=\mathrm{Cl}(2,3), \mathrm{Br}(4,5), \mathrm{I}(6)$

\section{Scheme 1}

To expand the scope of this reaction for the preparation of a series of 5-halo-1,2,3-triazoles we have carefully studied the behavior in this reaction of amides and esters of the 2-diazo-2cyanoacetic acid derivatives $\mathbf{1 a}-\mathbf{h}$, diazoketones $\mathbf{1} \mathbf{j}-\mathbf{n}$, the 2-aryl-2-diazoacetonitriles $\mathbf{7}, 2$ phosphonyl-2-diazoacetonitrile 8, diazomalononitrile 9, and the parent DAN 10. 
<smiles></smiles>

7<smiles>[R][PH](=O)C(=[W])C#N</smiles>

8<smiles>[R][PH](=O)c1nnn([TlH])c1[AlH2]</smiles>

11

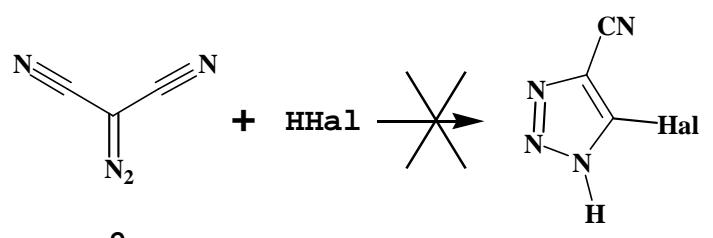

9<smiles>N#CC=[18O]</smiles><smiles>CC(C)(C)C(C)(C)C</smiles><smiles>c1c[nH]nn1</smiles>

\section{Scheme 2}

The compounds 1a-h were prepared by a three-step process from the active methylene compounds 12 by nitrosation, either in water with sodium nitrite and hydrochloric acid or in alcohol with ethyl nitrite followed by reduction of the 2-oxyimino derivatives, 13, formed with aluminum amalgam and treatment of the 2-aminoacetonitriles, 14, with sodium nitrite in dilute hydrochloric acid. The final products 1a-h were prepared in 20-30\% overall yields (Scheme 3 ).

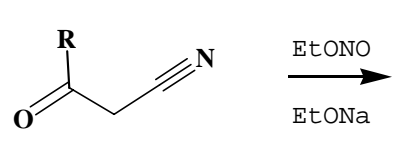

12a-h<smiles>[R]C(=O)C(C#N)=NO</smiles>

13a-h<smiles>[R]C(=O)C(N)C#N</smiles>

14a-h<smiles>[R]C(=O)C(=[W])C#N</smiles>

1a-h

$\mathrm{R}=\mathrm{NH}_{2}$ (a); NHMe (b); $\mathrm{NHC}_{6} \mathrm{H}_{11}$-cyclo (c); $\mathrm{NHPh}(\mathrm{d}) ; \mathrm{NHC}_{6} \mathrm{H}_{4} \mathrm{OMe}-4$ (e); $\mathrm{NHC}_{6} \mathrm{H}_{4} \mathrm{OMe}-4$ (f); $\mathrm{NHC}_{6} \mathrm{H}_{4} \mathrm{Br}-4(\mathrm{~g}) ; \mathrm{OEt}(\mathrm{h})$

\section{Scheme 3}

Compounds $\mathbf{1} \mathbf{j}-\mathbf{n}$ were prepared in one step from DAN by acylation with acyl chlorides or anhydrides (Scheme 4).

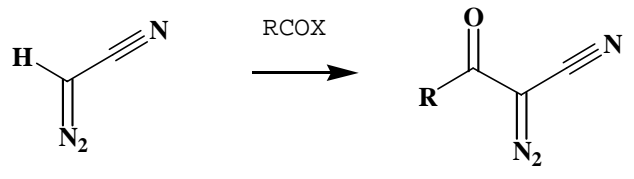

$$
\mathrm{X}=\mathrm{Cl} \text { or } \mathrm{RCO}
$$

1i-n

$\mathrm{R}=\mathrm{Me}(\mathrm{i}) ; \mathrm{Ph}(\mathrm{j}) ; \mathrm{C}_{6} \mathrm{H}_{4} \mathrm{OMe}-4$ (k); $\mathrm{C}_{6} \mathrm{H}_{4} \mathrm{Me}-4$ (l); $\mathrm{CF}_{3}(\mathrm{~m})$; quino linyl1-2 (n)

\section{Scheme 4}


We have found that diazomalononitrile, 9, and DAN, 10, as well as its $\alpha$-aryl derivatives, 7, do not react with hydrogen halides under these conditions. Instead, the amides and ester of 2diazo-2-cyanoacetic acid $\mathbf{1 a}-\mathbf{h}$, diazoketones $\mathbf{1} \mathbf{j}-\mathbf{l}$, and 2-phosphonyl-2-diazoacetonitrile $\mathbf{8}$ react easily with hydrogen halides to form the 5-halo-1,2,3-triazoles 3-, 5-, and 6-a-l and the 5-halo-4phosphonyl-1,2,3-triazoles $\mathbf{1 1}$ in $90-99 \%$ yield. Thus, this reaction is limited to diazo compounds bearing carbonyl or phosphonyl groups at the $\alpha$-position.

It is interesting to note that all of the diazo compounds that were transformed to 5-halotriazoles were able to form solid adducts with hydrogen halides which subsequently underwent heterocylization in the solid state. The appearance of hydroxy bond-stretching at $2500-3100 \mathrm{~cm}-$ 1 , the reduction in intensity of valence stretching of the cyano group, and the long-wave shift of the carbonyl band by about $50-90 \mathrm{~cm}^{-1}$ in the IR spectra of adducts $2 \mathbf{a}-\mathbf{l}$ in comparison with the parent diazonitriles indicate that the molecules of hydrogen halides are bound to the oxygen atom of the carbonyl-, and the nitrogen atom of cyano groups. We have found for diazoketones that if the shift of the carbonyl band in the IR of adducts is less than $50 \mathrm{~cm}^{-1}$ then the reaction would not occur. Thus, adducts of the diazoketones 2-, and 4-m and -n, in contrast to the other compounds 2-, and 4a-l, could not be transformed into the 5-halo-1,2,3-triazoles, 3-, and 5-m and -n.

Using all these facts we can conclude that intramolecular assistance of the carbonyl (or phosphonyl) group to the addition of $\mathrm{H}-\mathrm{Hal}$ to the cyano group is necessary for the reaction to take place of DAN with hydrogen halides leading to 5-halo-1,2,3-triazoles.

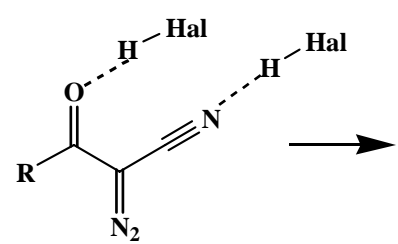

2a-n
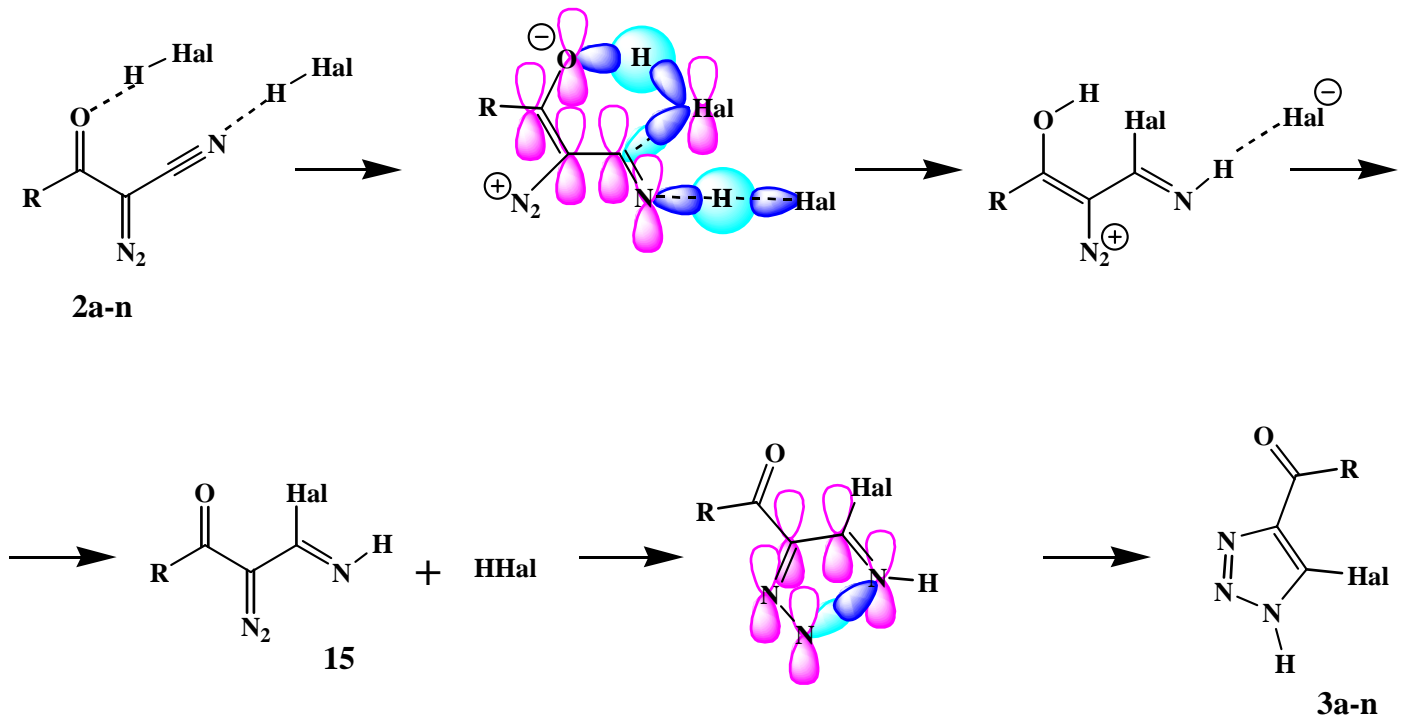

\section{Scheme 5}

We have studied the kinetics of cyclization of the diazonitriles $1 \mathrm{a}-1$ in a solution of hydrogen chloride in ethanol into the 5-chloro-1,2,3-triazoles 3a-1, and the solid-phase cyclization of adducts 4 into the 5-bromo-1,2,3-triazoles, 5. We found that the cyclization in solution is a firstorder reaction for the diazo compounds 1 , and second-order for $\mathrm{HCl}$. The activation energy for 
the transformation of DAN into 5-halo-1,2,3-triazoles has been determined by kinetic study as 18-24 Kcal mol${ }^{-1}$ in EtOH solution, and 15-18 $\mathrm{Kcal} \mathrm{mol}^{-1}$ in the solid state (Table 1). It has also been shown that the introduction of electron- donating substituents in the phenyl ring of the diazoketones increases the rate of this heterocyclization.

Table 1. Kinetic data on cyclization of diazo compounds $\mathbf{1}$ and adducts $\mathbf{4}$ to triazoles $\mathbf{3}$

\begin{tabular}{|c|c|c|c|c|c|}
\hline \multirow{2}{*}{ Comp. } & \multicolumn{3}{|c|}{$\mathrm{k}^{*} 10^{3}, \mathrm{M}^{-1} \mathrm{c}^{-1}$} & \multirow{2}{*}{$\begin{array}{c}\Delta \mathrm{H}^{\neq}, \mathrm{Kcal} \\
\mathrm{mol}^{-1}\end{array}$} & \multirow{2}{*}{$\begin{array}{c}\Delta \mathrm{S}^{\neq}, \text {cal mol } \\
{ }^{1} \mathrm{~K}^{-1}\end{array}$} \\
\hline & At $303 \mathrm{~K}$ & At $313 \mathrm{~K}$ & At $323 \mathrm{~K}$ & & \\
\hline $1 \mathbf{a}$ & $0.082 \pm 0.002$ & $1.07 \pm 0.02$ & $12.7 \pm 0.10$ & $20.8 \pm 0.2$ & $53.7 \pm 0.3$ \\
\hline $1 b$ & $0.014 \pm 0.002$ & $0.214 \pm 0.008$ & $2.55 \pm 0.08$ & $21.8 \pm 0.2$ & $55.5 \pm 0.3$ \\
\hline 1c & $0.0018 \pm 0.0003$ & $0.029 \pm 0.003$ & $0.398 \pm 0.009$ & $22.5 \pm 0.3$ & $56.0 \pm 0.4$ \\
\hline 1d & $0.523 \pm 0.004$ & $6.87 \pm 0.04$ & $8.02 \pm 0.05$ & $20.8 \pm 0.2$ & $55.3 \pm 0.4$ \\
\hline 1e & $0.189 \pm 0.003$ & $2.36 \pm 0.03$ & $24.4 \pm 0.03$ & $20.4 \pm 0.2$ & $53.1 \pm 0.3$ \\
\hline 1f & $0.128 \pm 0.005$ & $1.63 \pm 0.02$ & $17.8 \pm 0.02$ & $20.5 \pm 0.2$ & $53.1 \pm 0.5$ \\
\hline $1 g$ & $0.018 \pm 0.001$ & $0.24 \pm 0.01$ & $2.80 \pm 0.05$ & $20.7 \pm 0.2$ & $52.1 \pm 0.5$ \\
\hline 1h & $0.329 \pm 0.003$ & $3.82 \pm 0.04$ & $38.1 \pm 0.03$ & $19.8 \pm 0.2$ & $51.6 \pm 0.5$ \\
\hline $\mathbf{1 i}$ & $0.512 \pm 0.006$ & $4.89 \pm 0.06$ & $42.1 \pm 0.2$ & $18.2 \pm 0.3$ & $46.7 \pm 0.5$ \\
\hline $\mathbf{1 j}$ & $0.387 \pm 0.003$ & $4.08 \pm 0.05$ & $35.2 \pm 0.5$ & $19.0 \pm 0.2$ & $49.1 \pm 0.4$ \\
\hline $1 \mathbf{k}$ & $0.814 \pm 0.008$ & $6.88 \pm 0.08$ & $52.6 \pm 0.8$ & $17.2 \pm 0.5$ & $43.8 \pm 0.5$ \\
\hline 11 & $0.491 \pm 0.007$ & $4.57 \pm 0.05$ & $38.9 \pm 0.8$ & $18.0 \pm 0.3$ & $47.9 \pm 0.2$ \\
\hline $4 a$ & $0.061 \pm 0.005$ & $0.568 \pm 0.005$ & $4.5 \pm 0.3$ & $18.0 \pm 0.8$ & $46.1 \pm 0.4$ \\
\hline $4 b$ & $0.033 \pm 0.003$ & $0.327 \pm 0.006$ & $2.8 \pm 0.2$ & $18.4 \pm 0.5$ & $46.9 \pm 0.2$ \\
\hline $4 h$ & $0.094 \pm 0.003$ & $0.727 \pm 0.011$ & $5.1 \pm 0.2$ & $16.4 \pm 0.8$ & $41.2 \pm 0.3$ \\
\hline $4 i$ & $0.111 \pm 0.006$ & $0.775 \pm 0.006$ & $4.8 \pm 0.1$ & $15.6 \pm 0.5$ & $38.7 \pm 0.2$ \\
\hline $4 j$ & $0.139 \pm 0.006$ & $0.932 \pm 0.008$ & $5.8 \pm 0.2$ & $15.3 \pm 0.8$ & $37.9 \pm 0.2$ \\
\hline $4 \mathbf{k}$ & $0.122 \pm 0.005$ & $0.791 \pm 0.005$ & $4.6 \pm 0.3$ & $15.0 \pm 0.6$ & $36.8 \pm 0.8$ \\
\hline 41 & $0.118 \pm 0.006$ & $0.773 \pm 0.005$ & $4.6 \pm 0.5$ & $15.1 \pm 0.5$ & $37.1 \pm 0.2$ \\
\hline
\end{tabular}

It was proposed that diazoimidoyl chlorides $\mathbf{9}$ are intermediates in the transformation of DAN derivatives upon heating with hydrogen halides to 5-halo-1,2,3-triazoles. ${ }^{2}$ It is known that cis-addition of hydrogen halides to the cyano group is forbidden by the Woodward-Hoffmann rules, and the activation energy for this reaction is about $57 \mathrm{Kcal}^{7}$

\section{Why does the addition of hydrogen halides to the cyano group of DAN occur so easily?}

It is assisted by hydrogen bonding of HHal with the carbonyl or phosphonyl group and presumably occurs via a pseudopericyclic mechanism. ${ }^{8-12}$ The term pseudopericyclic reactions was introduced in Lemal ${ }^{13}$ and Snyder ${ }^{14}$ reports. According to these, a pseudopericyclic reaction is a concerted transformation in which primary changes in bonding compass a cyclic array of atoms, at one (or more) of which non-bonding and bonding atomic orbitals interchange roles. More lately, L. Burke, ${ }^{15,16}$ D. Birney, ${ }^{8-10,17-23}$ V. Bakulev and W. Fabian ${ }^{25-30}$ have used the idea 
of pseudopericyclic reactions in their work. Following these works, one can make generalizations for this type of reactions:

other type of symmetry;

- lower (or zero) activation energy;

- planarity;

- $\quad$ higher polarity of the transition state;

- and, there are reactions with one or more orbital disconnections in a closed loop of interacting orbitals.

Birney and his co-workers ${ }^{9,17-20}$ in a series of papers have extensively studied pseudopericyclic reactions with two disconnections. It was shown that the similar process of the addition of water to formylketene (Scheme 6) has low activation energy (6.3 $\left.\mathrm{Kcal} \mathrm{mol}^{-1}\right)$.

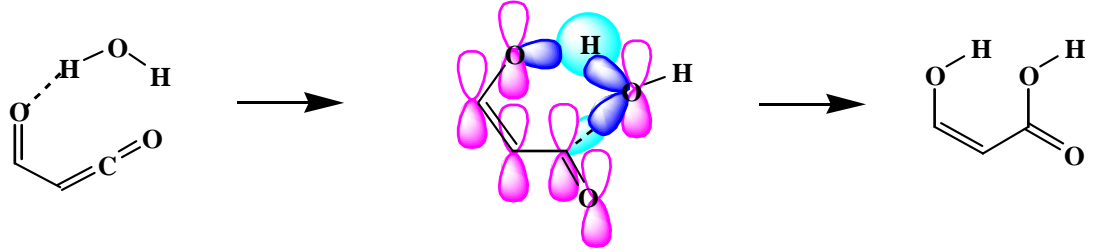

\section{Scheme 6}

This process and the addition of hydrogen halides to the cyano group of $\alpha$-carbonyl diazonitriles is similar and is consistent with the group-transfer type of pseudopericyclic reactions. In contrast to classic pericyclic group-transfer reactions, both these $\pi$-conjugated heteroatomic systems have the orbitals lying in the plane of molecule and new $\sigma$-bonding takes place from these orbitals rather than from $\pi$-orbitals.

The intermediate diazoimine $\mathbf{1 5}$ can cyclize to 1,2,3-triazoles $\mathbf{1}$ via two different mechanisms: electrocyclic, where the new $\mathrm{N}-\mathrm{N} \sigma$-bond occurs from the terminal orbitals of $\pi$ systems, and heteroelectrocyclic, where a new $\mathrm{N}-\mathrm{N} \sigma$-bond occurs from orbitals that are orthogonal to the $\pi$-system. In our previous work ${ }^{24,28,30}$ we showed that the cyclization of diazoimines into 1,2,3-triazoles goes via the heteroelectrocyclic mechanism without rotation of the terminal bonds of the $\pi$-conjugated systems, and has a low energy of activation (in the range 8.8-12.2 The classic electrocyclic route for these systems has a higher activation energy (about 21.9-26.0 Kcal mol-1).

The experimental energies of cyclization of the diazo compounds, 1, and adduct 4 (Table 1) are 17-22, and 15-18 Kcal mol ${ }^{-1}$. We can propose that this cyclization occurs via two steps. The first step is the addition of HHal to $\alpha$-carbonyl-diazonitriles via a pseudopericyclic grouptransfer reaction to form intermediate $\alpha$-diazo haloimines 15, and the second step is the 
cyclization of 15 to 5-halo-1,2,3-triazoles via the hetero-electrocyclic mechanism. Therefore, the cyclization of $\alpha$-carbonyl-diazonitriles is a tandem of pseudopericyclic processes.

\section{Conclusions}

General Procedures. The scope and limitations have been determined for the reaction of DAN derivatives with hydrogen halides leading to a variety of 5-chloro-, 5-bromo-, and 5-iodo-1,2,3triazoles. This reaction is limited to diazo compounds bearing groups at the $\alpha$-position that can form hydrogen-bonds with hydrogen halides and thus assist their addition to the cyano groups of the DAN derivatives. The mechanism of this new reaction includes the addition of two molecules to one molecule of $\alpha$-carbonyl- (or $\alpha$-phosphonyl) DAN, the carbonyl- (or phosphonyl-) function- assisted addition of HHal to the cyano group as a pseudopericyclic process, and hetero-electrocyclization of the intermediate diazo-imidoyl halides to give the final 5-halo-1,2,3-triazoles.

\section{Experimental Section}

General Procedures. NMR chemical shifts are given in $\delta$ units, and were recorded in $\mathrm{d}_{6}$-DMSO solution with a Bruker WH-250 spectrometer at $250 \mathrm{MHz}$; IR spectra in $\mathrm{KBr}$ were recorded using a UR-20 spectrometer. Mass-spectroscopy was performed on a Finnigan MAT-212 instrument using the direct inlet system, with electron energy $70 \mathrm{eV}$, source temperature $180^{\circ} \mathrm{C}$. All reaction mixtures and the products were examined by TLC on DC-Plastikfolen Kieselgel-60 F 254 plates. UV spectra were measured in EtOH. Melting points are uncorrected. 1H NMR The syntheses of the diazo compounds 1-a,-b,-h, 5-halo-1,2,3-triazoles 3-a,-b,-h were reported previously. DAN,,$^{31}$ 2-phosphonyl-2-diazoacetonitrile ${ }^{6}$ and 5-halo-4-phosphonyl-1,2,3-triazole ${ }^{6}$ were prepared as described.

\section{2-Hydroxyiminoacetonitriles 13a-h. General procedure}

Sodium ethoxide $(0.68 \mathrm{~g}, 0.1 \mathrm{~mol})$ was added to a suspension of $0.1 \mathrm{~mol} 2$-cyanoacetamides 12a-h in $150 \mathrm{~mL}$ ethanol. The solution was cooled to $0^{\circ} \mathrm{C}$ and $10 \mathrm{~mL}(0.12 \mathrm{~mol})$ ethyl nitrite was added. After stirring for $1 \mathrm{~h}, 10 \mathrm{~mL} \mathrm{HCl}$ was added. The precipitate was filtered and washed (hot ethanol). The filtrate was concentrated and cooled. The product was filtered, crystallized from ethanol and dried.

N-cyclo-Hexyl-2-amino-2-cyano-2-hydroxyimino-acetamide (13c). Yield, 78\%, white crystals, m.p. $210^{\circ} \mathrm{C}$. IR spectrum $/ \mathrm{cm}^{-1}, 3350,2960,2870,2225$ (CN), 1665 (CO). ${ }^{1} \mathrm{H}$ NMR (ppm), $8.21\left(1 \mathrm{H}\right.$, br. s, NH), 2.5-3.1 (1H, m, CH), 0.7-2.0 (10H, m, $\left.\mathrm{C}_{5} \mathrm{H}_{10}\right)$. Found, C, 55.4; $\mathrm{H}$, 6.7; $\mathrm{N}, 21.5$. $\mathrm{C}_{9} \mathrm{H}_{13} \mathrm{~N}_{3} \mathrm{O}_{2}$ requires $\mathrm{C}, 55.4 ; \mathrm{H}, 6.7 ; \mathrm{N}, 21.5 \%$. 
$N$-Phenyl-2-cyano-2-hydroxyimino-acetamide (13d). Yield, $81 \%$, white crystals, m.p. $230^{\circ} \mathrm{C}$. IR $/ \mathrm{cm}^{-1}$ : 3340, 3232, 3027, 2865, $2250(\mathrm{CN}), 1680$ (CO). ${ }^{1} \mathrm{H}$ NMR (ppm), 9.98 (1H, s, NH), 8.1-6.8 (5H, m, Ph). Found, C, 57.2; H, 3.8; N, 22.4. $\mathrm{C}_{9} \mathrm{H}_{7} \mathrm{~N}_{3} \mathrm{O}_{2}$ requires $\mathrm{C}, 57.1 ; \mathrm{H}, 3.7 ; \mathrm{N}$, $22.2 \%$.

$\boldsymbol{N}$-(p-Methoxyphenyl)-2-cyano-2-hydroxyimino-acetamide (13e). Yield, 73\%, white crystals, m.p. $218^{\circ} \mathrm{C}$. IR $/ \mathrm{cm}^{-1}$ : 3350, 3140, 2980, 2860, 2240 (CN), 1680 (CO). ${ }^{1} \mathrm{H}$ NMR (ppm), 9.40 $(1 \mathrm{H}, \mathrm{s}, \mathrm{NH}), 7.61(2 \mathrm{H}, \mathrm{d}, \mathrm{J}=9 \mathrm{~Hz}, \mathrm{ArH}), 6.88$ (2H, d, J=9 Hz, ArH), 3.77 (3H, s, OMe). Found, $\mathrm{C}, 54.5 ; \mathrm{H}, 4.2 ; \mathrm{N}, 19.0 . \mathrm{C}_{10} \mathrm{H}_{9} \mathrm{~N}_{3} \mathrm{O}_{3}$ requires $\mathrm{C}, 54.8 ; \mathrm{H}, 4.1 ; \mathrm{N}, 19.1 \%$.

$\boldsymbol{N}$-(p-Methylphenyl)-2-cyano-2-hydroxyimino-acetamide (13f). Yield, 77\%, white crystals, m.p. $244^{\circ} \mathrm{C}$. IR $/ \mathrm{cm}^{-1}$ : 3335, 3140, 2980, 2860, 2240 (CN), 1680 (CO). ${ }^{1} \mathrm{H}$ NMR (ppm), 10.26 $(1 \mathrm{H}, \mathrm{s}, \mathrm{NH}), 7.55(2 \mathrm{H}, \mathrm{d}, \mathrm{J}=8 \mathrm{~Hz}, \mathrm{ArH}), 7.12(2 \mathrm{H}, \mathrm{d}, \mathrm{J}=8 \mathrm{~Hz}, \mathrm{ArH}), 2.26$ (3H, s, Me). Found, C, 59.4; $\mathrm{H}, 4.5 ; \mathrm{N}, 21.0 . \mathrm{C}_{10} \mathrm{H}_{9} \mathrm{~N}_{3} \mathrm{O}_{2}$ requires $\mathrm{C}, 59.1 ; \mathrm{H}, 4.5 ; \mathrm{N}, 20.7 \%$.

$\mathrm{N}$-(p-Bromophenyl)-2-cyano-2-hydroxyimino-acetamide (13g). Yield, 71\%, white crystals, m.p. $245^{\circ} \mathrm{C}$. IR $/ \mathrm{cm}^{-1}$ : 3300, 3210, 3155, 3005, 2840, 2235 (CN), 1650 (CO). ${ }^{1} \mathrm{H}$ NMR (ppm), $10.51(1 \mathrm{H}, \mathrm{s}, \mathrm{NH}), 7.85-7.40\left(4 \mathrm{H}, \mathrm{m}, \mathrm{C}_{6} \mathrm{H}_{4}\right)$. Found, $\mathrm{C}, 40.4 ; \mathrm{H}, 2.3 ; \mathrm{N}, 16.6 . \mathrm{C}_{10} \mathrm{H}_{6} \mathrm{BrN}_{3} \mathrm{O}_{2}$ requires: $\mathrm{C}, 40.3 ; \mathrm{H}, 2.3 ; \mathrm{N}, 15.7 \%$.

\section{2-Aminoacetonitriles 14a-h. General procedure}

A solution of $0.02 \mathrm{~mol}$ oxime $7 \mathrm{in} 30 \mathrm{~mL}$ ethanol was dropped onto aluminum amalgam $(3.51 \mathrm{~g}$, $0.13 \mathrm{~mol})$ at $0^{\circ} \mathrm{C}$. After stirring for $4 \mathrm{~h}$ the reaction mixture was filtered and washed with hot ethanol. The filtrate was concentrated and cooled, the product filtered off, crystallized (EtOH) and dried.

2-Amino-2-cyanoacetamide (14a). Yield, 48\%, white crystals, m.p. $93^{\circ} \mathrm{C}$. Found, C, 59.4; $\mathrm{H}$, 8.4; $\mathrm{N}, 23.2$. $\mathrm{C}_{9} \mathrm{H}_{15} \mathrm{~N}_{3} \mathrm{O}$ requires: $\mathrm{C}, 59.6 ; \mathrm{H}, 8.3 ; \mathrm{N}, 23.2 \%$.

$\mathrm{N}$-Methyl-2-amino-2-cyanoacetamide (14b). Yield, $40 \%$, white crystals, m.p. $104^{\circ} \mathrm{C}$. Found, $\mathrm{C}, 63.2 ; \mathrm{H}, 5.7 ; \mathrm{N}, 22.0 . \mathrm{C}_{10} \mathrm{H}_{11} \mathrm{~N}_{3} \mathrm{O}$ requires: $\mathrm{C}, 63.5 ; \mathrm{H}, 5.9 ; \mathrm{N}, 22.2 \%$.

$\mathrm{N}$-cyclo-Hexyl-2-amino-2-cyanoacetamide (14c). Yield, $48 \%$, white crystals, m.p. $91-93{ }^{\circ} \mathrm{C}$. IR spectrum, 3365, 3320, 3190, 2951, 2882, 2255 (CN), 1665 (CO) cm ${ }^{-1} .{ }^{1} \mathrm{H}$ NMR (ppm), $7.87(1 \mathrm{H}$, $\mathrm{d}, \mathrm{J}=8 \mathrm{~Hz}, \mathrm{NH}), 4.39(1 \mathrm{H}, \mathrm{s}, \mathrm{CH}), 2.7-3.2(1 \mathrm{H}, \mathrm{m}, \mathrm{CH}), 0.5-2.2\left(10 \mathrm{H}, \mathrm{m}, \mathrm{C}_{5} \mathrm{H}_{10}\right)$. Found, $\mathrm{C}$, 59.4; H, 8.4; N, 23.2. $\mathrm{C}_{9} \mathrm{H}_{15} \mathrm{~N}_{3} \mathrm{O}$ requires: $\mathrm{C}, 59.6 ; \mathrm{H}, 8.3 ; \mathrm{N}, 23.2 \%$.

$\mathrm{N}$-Phenyl-2-amino-2-cyanoacetamide (14d). Yield, 46\%, white crystals, m.p. $117^{\circ} \mathrm{C}$. IR spectrum, 3410, 3323, 3073, 2942, $2260(\mathrm{CN}), 1707$ (CO) $\mathrm{cm}^{-1} .{ }^{1} \mathrm{H}$ NMR (ppm): 9.92 (1H, s, $\mathrm{NH}), 8.1-6.7(5 \mathrm{H}, \mathrm{m}, \mathrm{Ph}), 4.67(1 \mathrm{H}, \mathrm{s}, \mathrm{CH})$. Found, $\mathrm{C}, 61.6 ; \mathrm{H}, 5.4 ; \mathrm{N}, 24.1 . \mathrm{C}_{9} \mathrm{H}_{9} \mathrm{~N}_{3} \mathrm{O}$ requires: C, 61.7; H, 5.2; N, 24.0\%.

$\mathrm{N}$-(p-Methoxyphenyl)-2-amino-2-cyanoacetamide (14e). Yield, 42\%, white crystals, m.p. $129^{\circ} \mathrm{C}$. IR spectrum, 3410, 3315, 3025, 2945, 2850, $2260(\mathrm{CN}), 1700(\mathrm{CO}) \mathrm{cm}^{-1} .{ }^{1} \mathrm{H}$ NMR 9.40 $(1 \mathrm{H}, \mathrm{s}, \mathrm{NH}), 7.56(2 \mathrm{H}, \mathrm{d}, \mathrm{J}=9.0 \mathrm{~Hz}, \mathrm{ArH}), 6.85(2 \mathrm{H}, \mathrm{d}, \mathrm{J}=9.0 \mathrm{~Hz}, \mathrm{ArH}), 4.65(1 \mathrm{H}, \mathrm{s}, \mathrm{CH}), 3.75$ (3H, s, OMe). Found: C, 58.9; H, 5.6; N, 20.5. $\mathrm{C}_{10} \mathrm{H}_{11} \mathrm{~N}_{3} \mathrm{O}_{2}$ requires: $\mathrm{C}, 58.5 ; \mathrm{H}, 5.4 ; \mathrm{N}, 20.5 \%$.

$\boldsymbol{N}$-(p-Methylphenyl)-2-amino-2-cyanoacetamide (14f). Yield, 46\%, white crystals, m.p. $131{ }^{\circ} \mathrm{C}$. IR spectrum, 3428, 3242, 2940, 2890, 2252 (CN), 1700 (CO) $\mathrm{cm}^{-1} .{ }^{1} \mathrm{H}$ NMR 9.90 (1H, s, NH), 
$7.48(2 \mathrm{H}, \mathrm{d}, \mathrm{J}=8.0 \mathrm{~Hz}, \mathrm{ArH}), 7.10(2 \mathrm{H}, \mathrm{d}, \mathrm{J}=8.0 \mathrm{~Hz}, \mathrm{ArH}), 4.67(1 \mathrm{H}, \mathrm{s}, \mathrm{CH}), 2.25$ (3H, s, Me). Found: C, 63.6; H, 5.9; N, 22.1. $\mathrm{C}_{10} \mathrm{H}_{11} \mathrm{~N}_{3} \mathrm{O}$ requires: $\mathrm{C}, 63.5 ; \mathrm{H}, 5.9 ; \mathrm{N}, 22.2 \%$.

$\mathrm{N}$-(p-Bromophenyl)-2-amino-2-cyanoacetamide (14g). Yield, $40 \%$, white crystals, m.p. $143^{\circ} \mathrm{C}$. IR spectrum, 3405, 3335, 3050, 2910, $2240(\mathrm{CN}), 1685(\mathrm{CO}) \mathrm{cm}^{-1} .{ }^{1} \mathrm{H}$ NMR: $10.40(1 \mathrm{H}$, s, NH), 7.78-7.36 (4H, m, $\left.\mathrm{C}_{6} \mathrm{H}_{4}\right), 4.72(1 \mathrm{H}, \mathrm{s}, \mathrm{CH})$. Found: $\mathrm{C}, 42.5 ; \mathrm{H}, 3.2 ; \mathrm{N}, 16.3 . \mathrm{C}_{9} \mathrm{H}_{8} \mathrm{BrN}_{3} \mathrm{O}$ requires: $\mathrm{C}, 42.5 ; \mathrm{H}, 3.2 ; \mathrm{N}, 16.5 \%$.

Table 2. The diazo compounds, $1 \mathrm{a}-\mathrm{n}$

\begin{tabular}{|c|c|c|c|c|c|c|c|}
\hline \multirow{2}{*}{ Comp. } & \multirow{2}{*}{ m.p. ${ }^{\circ} \mathrm{C}$} & \multirow{2}{*}{$\begin{array}{c}\text { Yield } \\
(\%)\end{array}$} & \multicolumn{3}{|c|}{ IR $(\mathrm{KBr}), \mathrm{cm}^{-1}$} & \multirow{2}{*}{$\mathrm{m} / \mathrm{z},\left[\mathrm{M}^{+} \cdot\right](\%)$} & \multirow{2}{*}{ Formula } \\
\hline & & & $\mathrm{C}=\mathrm{O}$ & $\mathrm{CN}$ & $\mathrm{CN}_{2}$ & & \\
\hline 1a & 116 & 75 & 1684 & 2235 & 2151 & $110(25)$ & $\mathrm{C}_{3} \mathrm{H}_{2} \mathrm{~N}_{4} \mathrm{O}$ \\
\hline $1 b$ & 118 & 86 & 1668 & 2228 & 2151 & $124(12)$ & $\mathrm{C}_{4} \mathrm{H}_{4} \mathrm{~N}_{4} \mathrm{O}$ \\
\hline 1c & 101 & 74 & 1640 & 2238 & 2160 & $192(39)$ & $\mathrm{C}_{9} \mathrm{H}_{12} \mathrm{~N}_{4} \mathrm{O}$ \\
\hline 1d & 66 & 86 & 1660 & 2232 & 2150 & $186(43)$ & $\mathrm{C}_{9} \mathrm{H}_{6} \mathrm{~N}_{4} \mathrm{O}$ \\
\hline 1e & 137 & 79 & 1685 & 2235 & 2132 & $216(71)$ & $\mathrm{C}_{10} \mathrm{H}_{8} \mathrm{~N}_{4} \mathrm{O}_{2}$ \\
\hline 1f & 124 & 85 & 1670 & 2235 & 2145 & $200(100)$ & $\mathrm{C}_{10} \mathrm{H}_{8} \mathrm{~N}_{4} \mathrm{O}$ \\
\hline $1 g$ & 153 & 87 & 1680 & 2225 & 2130 & $266(64), 264(54)$ & $\mathrm{C}_{9} \mathrm{H}_{5} \mathrm{BrN}_{4} \mathrm{O}$ \\
\hline 1h & oil & 89 & 1720 & 2238 & 2145 & $139(66)$ & $\mathrm{C}_{5} \mathrm{H}_{5} \mathrm{~N}_{3} \mathrm{O}_{2}$ \\
\hline $1 \mathbf{i}$ & oil & 56 & 1654 & 2220 & 2115 & $109(15)$ & $\mathrm{C}_{4} \mathrm{H}_{3} \mathrm{~N}_{3} \mathrm{O}$ \\
\hline $1 \mathrm{j}$ & oil & 75 & 1770 & 2220 & 2135 & $171(54)$ & $\mathrm{C}_{9} \mathrm{H}_{5} \mathrm{~N}_{3} \mathrm{O}$ \\
\hline $1 \mathbf{k}$ & oil & 59 & 1750 & 225 & 2120 & $201(65)$ & $\mathrm{C}_{10} \mathrm{H}_{17} \mathrm{~N}_{3} \mathrm{O}_{2}$ \\
\hline 11 & oil & 68 & 1710 & 2230 & 2120 & $185(78)$ & $\mathrm{C}_{10} \mathrm{H}_{17} \mathrm{~N}_{3} \mathrm{O}$ \\
\hline $1 \mathrm{~m}$ & oil & 38 & 1710 & 2250 & 2130 & $163(17)$ & $\mathrm{C}_{4} \mathrm{~F}_{3} \mathrm{~N}_{3} \mathrm{O}$ \\
\hline $1 n$ & oil & 45 & 1714 & 2210 & 2115 & $222(8)$ & $\mathrm{C}_{12} \mathrm{H}_{6} \mathrm{~N}_{4} \mathrm{O}$ \\
\hline
\end{tabular}

\section{2-Cyano-2-diazoacetamides 1a-h (General procedure)}

A solution of $2.8 \mathrm{~g}(41 \mathrm{mmol})$ sodium nitrite in $15 \mathrm{~mL} \mathrm{H}_{2} \mathrm{O}$ was added to the solution of $40 \mathrm{mmol}$ of the amino-nitrile 8 in $120 \mathrm{~mL} 1 \mathrm{M} \mathrm{HCl}$ at $0^{\circ} \mathrm{C}$. For compounds 1a-g: The precipitate was filtered, washed with water and dried to yield 1a-g as yellow crystals. For compound 1h: the reaction mixture was extracted with ether $(3 \times 60 \mathrm{ml})$. The combined organics were dried $\left(\mathrm{Na}_{2} \mathrm{SO}_{4}\right)$, filtered and concentrated under reduced pressure. The residual oil was purified by flash chromatography (9:1 dichloromethane-petroleum) to yield $\mathbf{1 h}$ as a red oil.

\section{General procedure for acylation of DAN}

$10 \mathrm{mmol}$ acyl chloride (or acid anhydride) was added to the solution of $0.67 \mathrm{~g}$ (10 mmol) DAN and $1.4 \mathrm{~mL}(10 \mathrm{mmol}) \mathrm{Et}_{3} \mathrm{~N}$ in $50 \mathrm{~mL} \mathrm{CH}_{2} \mathrm{Cl}_{2}$ at -10 to $0^{\circ} \mathrm{C}$. After stirring at this temperature for $2 \mathrm{hr}$ the reaction mixture was washed by $3 \times 50 \mathrm{~mL}$ water. The organic layer was dried by $\mathrm{Na}_{2} \mathrm{SO}_{4}$ and concentrated under reduced pressure at $20^{\circ} \mathrm{C}$. The product was purified by chromatography on silica gel (60 mesh) with dichloromethane-petroleum (9:1) as eluent to yield 1i-n as yellow oils. 


\section{General procedure for preparation of adducts 2, 4 of diazonitrile with HHal}

A 4.54 $\mathrm{N}$ solution of HHal in dry diethyl ether $(4 \mathrm{~mL})$ was added to the solution of $1 \mathrm{mmol}$ diazo compound 1 in $50 \mathrm{~mL}$ dry diethyl ether at $0^{\circ} \mathrm{C}$. The precipitate was filtered, washed with $50 \mathrm{~mL}$ dry ether and dried at $0^{\circ} \mathrm{C}$ under reduced pressure.

\section{5-Halo-1,2,3-triazoles 3, 5, 6a-l. General procedure}

A solution of $1 \mathrm{mmol}$ diazoacetonitrile 1 in $20 \mathrm{~mL} \mathrm{CHCl}_{3}$ was added to $20 \mathrm{~mL} \mathrm{CHCl}_{3}$ saturated with HHal. The reaction mixture was stirred for $10 \mathrm{~h}$ at $40^{\circ} \mathrm{C}$. The solvent was removed under reduced pressure, the product crystallized from ethanol, and dried.

Table 3. The adducts 2 , and 4 diazo compound and HHal

\begin{tabular}{|c|c|c|c|c|c|c|c|c|}
\hline \multirow{2}{*}{ Comp. } & \multirow{2}{*}{$\begin{array}{c}\text { Yield } \\
(\%)\end{array}$} & \multicolumn{3}{|c|}{ IR $(\mathrm{KBr}), \mathrm{cm}^{-1}$} & \multicolumn{2}{|c|}{ Find, $\%$} & \multirow{2}{*}{$\begin{array}{c}\text { Calc., \% } \\
\text { Hal }\end{array}$} & \multirow{2}{*}{ Formula } \\
\hline & & $\mathrm{C}=\mathrm{O}$ & $\mathrm{CN}$ & $\mathrm{CN}_{2}$ & Hal & $\mathrm{Hal}^{-}$ & & \\
\hline $2 \mathrm{a}$ & 98 & 1690 & 2235 & 2155 & 38.7 & 38.7 & 38.8 & $\mathrm{C}_{3} \mathrm{H}_{4} \mathrm{Cl}_{2} \mathrm{~N}_{4} \mathrm{O}$ \\
\hline $2 b$ & 95 & 1685 & 2220 & 2150 & 36.3 & 36.2 & 36.0 & $\mathrm{C}_{4} \mathrm{H}_{6} \mathrm{Cl}_{2} \mathrm{~N}_{4} \mathrm{O}$ \\
\hline $2 \mathrm{c}$ & 98 & 1680 & 2220 & 2160 & 26.6 & 26.5 & 26.7 & $\mathrm{C}_{9} \mathrm{H}_{10} \mathrm{Cl}_{2} \mathrm{~N}_{4} \mathrm{O}$ \\
\hline $2 d$ & 99 & 1675 & 2225 & 2153 & 27.4 & 27.3 & 27.4 & $\mathrm{C}_{9} \mathrm{H}_{2} \mathrm{Cl}_{2} \mathrm{~N}_{4} \mathrm{O}$ \\
\hline $4 a$ & 96 & 1700 & 2255 & 2157 & 58.8 & 58.8 & 58.8 & $\mathrm{C}_{3} \mathrm{H}_{4} \mathrm{Br}_{2} \mathrm{~N}_{4} \mathrm{O}$ \\
\hline $4 b$ & 98 & 1664 & 2231 & 2146 & 56.0 & 56.0 & 55.9 & $\mathrm{C}_{4} \mathrm{H}_{6} \mathrm{Br}_{2} \mathrm{~N}_{4} \mathrm{O}$ \\
\hline $4 c$ & 99 & 1660 & 2225 & 2150 & 45.1 & 44.9 & 45.1 & $\mathrm{C}_{9} \mathrm{H}_{10} \mathrm{Br}_{2} \mathrm{~N}_{4} \mathrm{O}$ \\
\hline $4 d$ & 98 & 1665 & 2220 & 2140 & 45.8 & 45.3 & 45.9 & $\mathrm{C}_{9} \mathrm{H}_{2} \mathrm{Br}_{2} \mathrm{~N}_{4} \mathrm{O}$ \\
\hline $4 \mathrm{e}$ & 97 & 1645 & 2220 & 2145 & 42.4 & 42.4 & 42.3 & $\mathrm{C}_{10} \mathrm{H}_{10} \mathrm{Br}_{2} \mathrm{~N}_{4} \mathrm{O}_{2}$ \\
\hline $4 f$ & 99 & 1668 & 2215 & 2135 & 44.1 & 44.1 & 44.1 & $\mathrm{C}_{10} \mathrm{H}_{10} \mathrm{Br}_{2} \mathrm{~N}_{4} \mathrm{O}$ \\
\hline $4 g$ & 99 & 1670 & 2230 & 2140 & 56.3 & 37.9 & 56.2 & $\mathrm{C}_{9} \mathrm{H}_{7} \mathrm{Br}_{3} \mathrm{~N}_{4} \mathrm{O}$ \\
\hline $4 \mathrm{~h}$ & 98 & 1670 & 2220 & 2150 & 53.1 & 53.0 & 53.1 & $\mathrm{C}_{5} \mathrm{H}_{7} \mathrm{Br}_{2} \mathrm{~N}_{3} \mathrm{O}_{2}$ \\
\hline $4 \mathrm{i}$ & 87 & 1645 & 2220 & 2135 & 59.1 & 58.7 & 59.0 & $\mathrm{C}_{4} \mathrm{H}_{5} \mathrm{Br}_{2} \mathrm{~N}_{3} \mathrm{O}$ \\
\hline $4 j$ & 89 & 1648 & 2220 & 2115 & 48.1 & 47.8 & 48.0 & $\mathrm{C}_{9} \mathrm{H}_{7} \mathrm{Br}_{2} \mathrm{~N}_{3} \mathrm{O}$ \\
\hline $4 \mathrm{k}$ & 92 & 1640 & 2220 & 2135 & 44.1 & 44.0 & 44.0 & $\mathrm{C}_{10} \mathrm{H}_{9} \mathrm{Br}_{2} \mathrm{~N}_{3} \mathrm{O}_{2}$ \\
\hline 41 & 96 & 1650 & 2220 & 2130 & 46.2 & 46.2 & 46.1 & $\mathrm{C}_{10} \mathrm{H}_{9} \mathrm{Br}_{2} \mathrm{~N}_{4} \mathrm{O}$ \\
\hline $4 \mathrm{~m}$ & 98 & 1670 & 2230 & 2120 & 49.3 & 49.1 & 49.2 & $\mathrm{C}_{4} \mathrm{H}_{2} \mathrm{Br}_{2} \mathrm{~F}_{3} \mathrm{~N}_{3} \mathrm{O}$ \\
\hline $4 n$ & 90 & 1685 & 2210 & 2115 & 41.5 & 41.4 & 41.6 & $\mathrm{C}_{12} \mathrm{H}_{8} \mathrm{Br}_{2} \mathrm{~N}_{4} \mathrm{O}$ \\
\hline
\end{tabular}

5-Chloro-1,2,3-triazole-4-carboxamide (3a). Yield 87\%, white crystals, m.p. $192-4{ }^{\circ} \mathrm{C}$. IR, $3485(\mathrm{NH}), 1685(\mathrm{C}=\mathrm{O}) \mathrm{cm}^{-1}$. UV, $\lambda_{\max }, \mathrm{nm},(\log \varepsilon): 231$ (3.81). Found: $\mathrm{C}, 24.7 ; \mathrm{H}, 1.9 ; \mathrm{Cl}$, 24.2; N, 38.6. $\mathrm{C}_{3} \mathrm{H}_{3} \mathrm{ClN}_{4} \mathrm{O}$ requires $\mathrm{C}, 24.6 ; \mathrm{H}, 2.1 ; \mathrm{Cl}, 24.2 ; \mathrm{N}, 38.2 \%$.

$N$-Methyl-5-chloro-1,2,3-triazole-4-carboxamide (3b). Yield 91\%, white crystals, m.p. 192$3^{\circ} \mathrm{C}$. IR, $3390(\mathrm{NH}), 1640(\mathrm{C}=\mathrm{O}) \mathrm{cm}^{-1} . \mathrm{UV}, \lambda_{\max }, \mathrm{nm},(\log \varepsilon): 207$ (3.84), 237 (3.91). ${ }^{1} \mathrm{H}$ NMR $8.82\left(1 \mathrm{H}\right.$, br s, NH), $2.86(3 \mathrm{H}, \mathrm{d}, \mathrm{Me})$. Found: C, 92.8; H, 3.0; Cl, 21.9; N, 34.9. $\mathrm{C}_{3} \mathrm{H}_{5} \mathrm{ClN}_{4} \mathrm{O}$ requires: $\mathrm{C}, 29.9 ; \mathrm{H}, 3.1 ; \mathrm{Cl}, 22.1 ; \mathrm{N}, 34.9 \%$. 
N-cyclo-Hexyl-5-chloro-1,2,3-triazole-4-carboxamide (3c). Yield 69\%, white crystals, m.p. 186-7 $7^{\circ}$ C. IR, $3410(\mathrm{NH}), 3085,2930,2850(\mathrm{CH}), 1650(\mathrm{C}=\mathrm{O}) \mathrm{cm}^{-1}$. UV, $\lambda_{\max }, \mathrm{nm},(\log \varepsilon): 237$ (4.28). ${ }^{1} \mathrm{H}$ NMR $8.02(1 \mathrm{H}, \mathrm{d}, 8.0 \mathrm{~Hz}, \mathrm{NH}), 2.9-3.0(1 \mathrm{H}, \mathrm{m}, \mathrm{NCH}), 0.5-2.2\left(10 \mathrm{H}, \mathrm{m}, \mathrm{C}_{6} \mathrm{H}_{10}\right)$. Found: C, 47.5; H, 5.9; Cl, 15.3; N, 24.5. $\mathrm{C}_{9} \mathrm{H}_{13} \mathrm{ClN}_{4} \mathrm{O}$ requires: $\mathrm{C}, 47.3 ; \mathrm{H}, 5.7 ; \mathrm{Cl}, 15.5 ; \mathrm{N}$, $24.5 \%$.

$N$-Phenyl-5-chloro-1,2,3-triazole-4-carboxamide (3d). Yield 87\%, white crystals, m.p. 193$5^{\circ} \mathrm{C}$. IR $3395(\mathrm{NH}), 3120,2975,2885(\mathrm{CH}), 1680(\mathrm{C}=\mathrm{O}) \mathrm{cm}^{-1}$. UV, $\lambda_{\max }, \mathrm{nm},(\log \varepsilon): 241(4.18)$. ${ }^{1} \mathrm{H}$ NMR 10.43 (1H, s, NH), 7.10-7.95 (5H, m, Ph). Found: C, 48.8; H, 3.7; Cl, 15.9; N, 25.1. $\mathrm{C}_{9} \mathrm{H}_{7} \mathrm{ClN}_{4} \mathrm{O}$ requires $\mathrm{C}, 48.6 ; \mathrm{H}, 3.7 ; \mathrm{Cl}, 15.9 ; \mathrm{N}, 25.2 \%$.

$\boldsymbol{N}$-p-Methoxyphenyl-5-chloro-1,2,3-triazole-4-carboxamide (3e). Yield 84\%, white crystals, m.p. $205-7^{\circ} \mathrm{C}$. IR: $3395(\mathrm{NH}), 3140,2960,2835(\mathrm{CH}), 1680(\mathrm{C}=\mathrm{O}) \mathrm{cm}^{-1}$. UV, $\lambda_{\max }, \mathrm{nm},(\log \varepsilon)$ : 240 (4.05). ${ }^{1} \mathrm{H}$ NMR: 10.20 (1H, s, NH), 7.65 (2H, d, $\left.9.0 \mathrm{~Hz}, \mathrm{ArH}\right), 6.87$ (2H, d, $\left.9.0 \mathrm{~Hz}, \mathrm{ArH}\right)$, $3.75(3 \mathrm{H}, \mathrm{s}, \mathrm{OMe})$. Found: $\mathrm{C}, 47.2 ; \mathrm{H}, 3.7 ; \mathrm{Cl}, 14.2 ; \mathrm{N}, 22.0 . \mathrm{C}_{10} \mathrm{H}_{9} \mathrm{ClN}_{4} \mathrm{O}_{2}$ requires: $\mathrm{C}, 47.5 ; \mathrm{H}$, 3.6; Cl, 14.0; N, 22.3\%.

$\boldsymbol{N}$-p-Methylphenyl-5-chloro-1,2,3-triazole-4-carboxamide (3f). Yield 87\%, white crystals, m.p. 197-9 ${ }^{\circ}$ C. IR: $3395(\mathrm{NH}), 3140,2965,2855(\mathrm{CH}), 1680(\mathrm{C}=\mathrm{O}) \mathrm{cm}^{-1}$. UV, $\lambda_{\max }, \mathrm{nm},(\log \varepsilon)$ : 243 (4.10). ${ }^{1} \mathrm{H}$ NMR: 10.20 (1H, s, NH), 7.65 (2H, d, $\left.9.0 \mathrm{~Hz}, \mathrm{ArH}\right), 7.10$ (2H, d, $\left.9.0 \mathrm{~Hz}, \mathrm{ArH}\right)$, $2.24(3 \mathrm{H}, \mathrm{s}, \mathrm{OMe})$. Found: $\mathrm{C}, 51.0 ; \mathrm{H}, 3.9 ; \mathrm{Cl}, 15.2 ; \mathrm{N}, 23.8 . \mathrm{C}_{10} \mathrm{H}_{9} \mathrm{ClN}_{4} \mathrm{O}$ requires: $\mathrm{C}, 50.8 ; \mathrm{H}$, 3.8; Cl, 15.0; N, $23.7 \%$.

Ethyl 5-chloro-1,2,3-triazole-4-carboxylate (3h). Yield 59\%, white crystals, m.p. $74-7^{\circ} \mathrm{C}$. IR: $3540(\mathrm{NH}), 1715(\mathrm{C}=\mathrm{O}) \mathrm{cm}^{-1}$. UV, $\lambda_{\max }, \mathrm{nm},(\log \varepsilon): 237$ (4.08). ${ }^{1} \mathrm{H}$ NMR 4.47 (2H, q, $7.2 \mathrm{~Hz}$, $\left.\mathrm{CH}_{2}\right), 1.39(3 \mathrm{H}, \mathrm{t}, 7.2 \mathrm{~Hz}, \mathrm{Me})$. Found: $\mathrm{C}, 34.0 ; \mathrm{H}, 3.3 ; \mathrm{Cl}, 19.9 ; \mathrm{N}, 23.8 . \mathrm{C}_{5} \mathrm{H}_{6} \mathrm{ClN}_{3} \mathrm{O}_{2}$ requires: C, 34.2; H, 3.4; Cl, 20.2; N, 23.9\%.

5-Chloro-4-phenylcarbonyl-1,2,3-triazole (3j). Yield 88\%, white crystals, m.p. $152-3^{\circ} \mathrm{C}$. IR: $1645(\mathrm{C}=\mathrm{O}) \mathrm{cm}^{-1} . \mathrm{UV}, \lambda_{\max }, \mathrm{nm},(\log \varepsilon): 203$ (3.97), 258 (4.07). Found: C, 52.4; H, 3.2; Cl, 16.8; $\mathrm{N}, 20.5 . \mathrm{C}_{9} \mathrm{H}_{6} \mathrm{ClN}_{3} \mathrm{O}$ requires: C, 52.1; $\mathrm{H}, 2.9 ; \mathrm{Cl}, 17.1 ; \mathrm{N}, 20.2 \%$.

5-Bromo-1,2,3-triazole-4-carboxamide (5a). Yield 70\%, white crystals, m.p. $181-3^{\circ} \mathrm{C}$. IR: $3385(\mathrm{NH}), 1695(\mathrm{C}=\mathrm{O}) \mathrm{cm}^{-1}$. UV, $\lambda_{\max }, \mathrm{nm},(\log \varepsilon): 234$ (3.72). Found: $\mathrm{C}, 18.7 ; \mathrm{H}, 1.8 ; \mathrm{Br}$, 41.4; N, 29.5. $\mathrm{C}_{3} \mathrm{H}_{3} \mathrm{BrN}_{4} \mathrm{O}$ requires: $\mathrm{C}, 18.9 ; \mathrm{H}, 1.6 ; \mathrm{Br}, 41.8 ; \mathrm{N}, 29.3 \%$.

$N$-Methyl-5-bromo-1,2,3-triazole-4-carboxamide (5b). Yield 67\%, white crystals, m.p. 184$6^{\circ} \mathrm{C}$. IR: $3400(\mathrm{NH}), 1650(\mathrm{C}=\mathrm{O}) \mathrm{cm}^{-1}$. UV, $\lambda_{\max }, \mathrm{nm},(\log \varepsilon): 232(3.96) .{ }^{1} \mathrm{H}$ NMR $8.82(1 \mathrm{H}, \mathrm{br}$ s, NH), $2.83(3 \mathrm{H}, \mathrm{d}, \mathrm{NMe})$. Found: $\mathrm{C}, 23.4 ; \mathrm{H}, 2.7 ; \mathrm{Br}, 39.1 ; \mathrm{N}, 27.7 . \mathrm{C}_{4} \mathrm{H}_{5} \mathrm{BrN}_{4} \mathrm{O}$ requires: $\mathrm{C}$, $23.4 ; \mathrm{H}, 2.5 ; \mathrm{Br}, 39.0 ; \mathrm{N}, 27.3 \%$.

$\boldsymbol{N}$-cyclo-Hexyl-5-bromo-1,2,3-triazole-4-carboxamide (5c). Yield 90\%, white crystals, m.p. 188-190 ${ }^{\circ} \mathrm{C}$. IR: $3405(\mathrm{NH}), 3085,2925,2850(\mathrm{CH}), 1650(\mathrm{C}=\mathrm{O}) \mathrm{cm}^{-1}$. UV, $\lambda_{\max }, \mathrm{nm},(\log \varepsilon)$ : 237 (4.28). ${ }^{1} \mathrm{H}$ NMR: 8.02 (1H, d, $\left.8.0 \mathrm{~Hz}, \mathrm{NH}\right), 2.80-2.98$ (1H, m, NCH), 0.80-2.05 (10H, m, $\mathrm{C}_{6} \mathrm{H}_{10}$ ). Found, \%: C, 39.6; H, 4.9; Br, 29.6; N, 20.9. $\mathrm{C}_{9} \mathrm{H}_{13} \mathrm{BrN}_{4} \mathrm{O}$. Calc., \%: C, 39.6; H, 4.8; Br, $29.3 ; \mathrm{N}, 20.5$.

$\boldsymbol{N}$-Phenyl-5-bromo-1,2,3-triazole-4-carboxamide (5d). Yield 89\%, white crystals, m.p. 186$8^{\circ} \mathrm{C}$. IR: $3400(\mathrm{NH}), 3105,2972,2887(\mathrm{CH}), 1680(\mathrm{C}=\mathrm{O}) \mathrm{cm}^{-1}$. UV, $\lambda_{\max }, \mathrm{nm},(\log \varepsilon): 241$ 
(4.18). ${ }^{1} \mathrm{H}$ NMR: 10.43 (1H, s, NH), 7.10-7.95 (5H, m, Ph). Found: C, 40.7; H, 2.7; Br, 30.0; N, 20.7. $\mathrm{C}_{9} \mathrm{H}_{7} \mathrm{BrN}_{4} \mathrm{O}$. Calc. C, 40.5; H, 2.6; Br, 30.0; N, 21.0\%.

Ethyl 5-bromo-1,2,3-triazole-4-carboxylate (5h). Yield 94\%, white crystals, m.p. $71-4^{\circ} \mathrm{C}$. IR: $3445(\mathrm{NH}), 1705(\mathrm{C}=\mathrm{O}) \mathrm{cm}^{-1} . \mathrm{UV}, \lambda_{\max }, \mathrm{nm},(\log \varepsilon): 237$ (3.84). NMR: 4.49 (2H, q, 7.2 Hz, $\mathrm{CH}_{2}$ ), 1.33 (3H, t, 7.2 Hz, Me). Found: C, 27.4; H, 3.1; Br, 36.2; N, 18.9. $\mathrm{C}_{5} \mathrm{H}_{6} \mathrm{BrN}_{3} \mathrm{O}_{2}$ requires C, 27.3; H, 2.8; Br, 36.3; N, 19.1\%.

5-Bromo-4-methylcarbonyl-1,2,3-triazole (5i). Yield $86 \%$, white crystals, m.p. $58-62^{\circ} \mathrm{C}$. IR: $1750(\mathrm{C}=\mathrm{O}) \mathrm{cm}^{-1}$. Found: $\mathrm{C}, 25.4 ; \mathrm{H}, 2.2 ; \mathrm{Br}, 42.1 ; \mathrm{N}, 22.1 . \mathrm{C}_{4} \mathrm{H}_{4} \mathrm{BrN}_{3} \mathrm{O}$ requires: $\mathrm{C}, 25.2 ; \mathrm{H}$, $2.1 ; \mathrm{Br}, 42.0 ; \mathrm{N}, 22.1 \%$.

5-Bromo-4-phenylcarbonyl-1,2,3-triazole (5j). Yield 92\%, white crystals, m.p. $137-8^{\circ} \mathrm{C}$. IR: $1650(\mathrm{C}=\mathrm{O}) \mathrm{cm}^{-1}$. UV, $\lambda_{\max }, \mathrm{nm},(\log \varepsilon): 257$ (3.95), 241 (3.75). Found: $\mathrm{C}, 43.2 ; \mathrm{H}, 2.5 ; \mathrm{Br}, 31.6$; $\mathrm{N}, 16.9$. $\mathrm{C}_{9} \mathrm{H}_{6} \mathrm{BrN}_{3} \mathrm{O}$ requires: $\mathrm{C}, 42.9 ; \mathrm{H}, 2.4 ; \mathrm{Br}, 31.7 ; \mathrm{N}, 16.7 \%$.

5-Bromo-4-p-methoxyphenylcarbonyl-1,2,3-triazole (5k). Yield 97\%, white crystals, m.p. 87$93^{\circ} \mathrm{C}$. IR: $3170(\mathrm{CH}), 1720(\mathrm{C}=\mathrm{O}) \mathrm{cm}^{-1}$. Found: $\mathrm{C}, 43.2 ; \mathrm{H}, 3.0 ; \mathrm{Br}, 29.0 ; \mathrm{N}, 15.2 . \mathrm{C}_{10} \mathrm{H}_{8} \mathrm{BrN}_{3} \mathrm{O}_{2}$ requires: $\mathrm{C}, 43.0 ; \mathrm{H}, 2.9 ; \mathrm{Br}, 28.9 ; \mathrm{N}, 15.0 \%$.

5-Bromo-4-p-methylphenylcarbonyl-1,2,3-triazole (5l). Yield 89\%, white crystals, m.p. 98$100^{\circ} \mathrm{C}$. IR: $2970(\mathrm{CH}), 1700(\mathrm{C}=\mathrm{O}) \mathrm{cm}^{-1}$. Found: C, 45.6; H, 3.0; Br, 30.6; N, 16.0. $\mathrm{C}_{10} \mathrm{H}_{8} \mathrm{BrN}_{3} \mathrm{O}$ requires: $\mathrm{C}, 45.1 ; \mathrm{H}, 3.0 ; \mathrm{Br}, 30.0 ; \mathrm{N}, 15.8 \%$.

5-Iodo-1,2,3-triazole-4-carboxamide (3a). Yield 70\%, white crystals, m.p. $181-3^{\circ} \mathrm{C}$. IR: 3385 $(\mathrm{NH}), 1670(\mathrm{C}=\mathrm{O}) \mathrm{cm}^{-1} . \mathrm{UV}, \lambda_{\max }, \mathrm{nm},(\log \varepsilon): 218$ (3.96), 242 (3.77). Found: C, 18.7; H, 1.8; N, 29.5. $\mathrm{C}_{3} \mathrm{H}_{3} \mathrm{IN}_{4} \mathrm{O}$ requires: $\mathrm{C}, 15.1 ; \mathrm{H}, 1.3 ; \mathrm{N}, 23.5 \%$.

$N$-Methyl-5-iodo-1,2,3-triazole-4-carboxamide (3b). Yield 93\%, white crystals, m.p. $182-4^{\circ} \mathrm{C}$. IR: $3330(\mathrm{NH}), 1660(\mathrm{C}=\mathrm{O}) \mathrm{cm}^{-1}$. UV, $\lambda_{\max }, \mathrm{nm},(\log \varepsilon): 219$ (3.94). NMR: $8.9(1 \mathrm{H}$, br s, NH), $2.81(3 \mathrm{H}, \mathrm{s}, \mathrm{NMe})$. Found: $\mathrm{C}, 19.4 ; \mathrm{H}, 1.8 ; \mathrm{N}, 22.5 . \mathrm{C}_{4} \mathrm{H}_{5} \mathrm{IN}_{4} \mathrm{O}$ requires: $\mathrm{C}, 19.1 ; \mathrm{H}, 2.0 ; \mathrm{N}$, $22.2 \%$.

$N$-Phenyl-5-iodo-1,2,3-triazole-4-carboxamide (3d). Yield 45\%, white crystals, m.p. $184-7^{\circ} \mathrm{C}$. IR: $1650(\mathrm{C}=\mathrm{O}) \mathrm{cm}^{-1}$. UV, $\lambda_{\max }, \mathrm{nm},(\log \varepsilon): 256$ (4.08). Found: C, 30.5; H, 3.5; N, 11.9. $\mathrm{C}_{9} \mathrm{H}_{6} \mathrm{IN}_{3} \mathrm{O}$. Calc.: C, 30.6; H, 3.4; N, 11.9\%.

Ethyl 5-iodo-1,2,3-triazole-4-carboxylate (3h). Yield $82 \%$, white crystals, m.p. $67-8^{\circ} \mathrm{C}$. IR: $3485(\mathrm{NH}), 1730(\mathrm{C}=\mathrm{O}) \mathrm{cm}^{-1}$. UV, $\lambda_{\max }, \mathrm{nm},(\log \varepsilon): 241$ (3.75). NMR: 4.48 (2H, q, $7.3 \mathrm{~Hz}$, $\left.\mathrm{CH}_{2}\right), 1.37(3 \mathrm{H}, \mathrm{t}, 7.3 \mathrm{~Hz}, \mathrm{Me})$. Found, \%: C, 22.9; H, 2.6; N, 15.6. $\mathrm{C}_{5} \mathrm{H}_{6} \mathrm{IN}_{3} \mathrm{O}_{2}$ requires: C, 22.5; $\mathrm{H}, 2.3 ; \mathrm{N}, 15.7 \%$.

Kinetic experiments. Kinetic data were obtained by UV spectroscopy at the absorption maxim $\left(\lambda_{\max }=254 \mathrm{~nm}\right)$ of the diazo compounds 1 by sampling, acidification to $\mathrm{pH} 4-5$ with a solution of $\mathrm{HCl}$ in ethanol, followed by dilution with ethanol of the reaction mixtures kept at $30^{\circ}, 40^{\circ}$, or $50^{\circ} \mathrm{C}$. The concentrations of the diazo compounds were $0.3 \mathrm{mM}$, and $3 \mathrm{M} \mathrm{HCl}$. Kinetic data for the solid cyclization of adducts 2 were obtained by IR spectroscopy at the absorption of diazo group of the mixture of compounds $2(0.11 \mathrm{~mol})$ and $\mathrm{KBr}$. The reaction rate constant was calculated using a linear regression program. 


\section{Acknowledgments}

This research was made possible in part by Award No. RC1-2393-EK-02 of the U.S. Civilian Research \& Development Foundation for the Independent States of the Former Soviet Union (CRDF). We also thank the Russian Foundation for Basic Research (Grant 02-03-96421).

\section{References and Notes}

${ }^{\dagger}$ Part 7 in the series, "Heterocyclization of Compounds Containing Diazo and Cyano Groups". For previous paper in this series, see ref. 1.

1. Morzherin, Yu.Yu.; Kolobov, M.Yu.; Mokrushin, V.S.; Brauer, M.; Anders, E.; Bakulev, V.A. Khim. Geterotsikl. Soedin 2000, 1, 26.

2. Shafran, Yu.M.; Bakulev, V.A.; Mokrushin, V.S.; Pushkareva, Z.V. Khim. Geterotsikl. Soedin. 1982, 12, 1696.

3. Shealy, Y. F.; O’Dell, C.A. J. Med. Chem. 1966, 9, 733.

4. Shafran, Yu.M.; Bakulev, V.A.; Mokrushin, V.S.; Alekseev, S.G. Khim. Geterotsikl. Soedin. 1984, 9, 1266.

5. Shafran, Yu.M.; Morzherin, Yu.Yu.; Bakulev, V.A.; Mokrushin, V.S.; Zhurn. Organ. Khimii 1990, 26, 627.

6. Mikityuk, A.D.; Strepikheev, Yu.A.; Khokhlov, P.S. Zhurn. Obsh. Khimii 1986, 56, 1911.

7. Alagona, G. Theochem. 1982, 91, 263.

8. Zhou, C.; Birney, D. M. J. Am. Chem. Soc. 2002, 124, 5231.

9. Birney, D. M.; Wagenseller, P. E. J. Am. Chem. Soc. 1994, 116, 6262.

10. Birney, D.; Lim, T. K.; Koh, J. H. P.; Pool, B. R.; White, J. M. J. Am. Chem. Soc. 2002,124, 5091.

11. Shumway, W. W.; Dalley, N. K.; Birney, D. M. J. Org. Chem. 2001; 66, 5832.

12. Birney, D. M. J. Am. Chem. Soc. 2000, 122, 10917.

13. Ross, J. A.; Seiders, R. P.; Lemal, D. M. J. Am. Chem. Soc 1976, 98, 4325.

14. Snyder, J. P. J. Am. Chem. Soc. 1980, 102, 2861.

15. Burke, L. A.; Elguero, J.; Leroy, G.; Sana, M. J. Am. Chem. Soc. 1976, 98, 1685.

16. Burke, L. A.; Leroy, G.; Nguyen M.T. J. Am. Chem. Soc. 1978, 100, 3668.

17. Birney, D. M.; Ham, S.; Unruh, G. R. J. Am. Chem. Soc. 1997, 119, 4509.

18. Ham, S.; Birney, D. M. Tetrahedron Lett. 1994, 35, 8113.

19. Wagenseller, P. E.; Birney, D. M.; Roy, D. J. Org. Chem. 1995, 60, 2853.

20. Ham, S.; Birney, D. M. J. Org. Chem. 1996, 61, 3962.

21. Birney, D. M. J. Org. Chem. 1996, 61, 243.

22. Matsui, H.; Zuckerman, E. J.; Katagiri, N.; Sugihara, T.; Kaneko, C.; Ham, S.; Birney, D. M. J. Phys. Chem. 1997, 101, 3936. 
23. Birney, D. M.; Xu, X. L.; Ham, S.; Huang, X. M. J. Org. Chem. 1997, 62, 7114.

24. Bakulev, V. A.; Gloriozov, I. P. Khim. Geterotsikl. Soed. 1989, 504.

25. Bakulev, V. A.; Morzherin, Y. Y.; Lebedev, A. T.; Dankova, E. F.; Kolobov, M. Y.; Shafran, Y. M. Bull. Soc. Chim. Belg. 1993, 102, 493 and references therein.

26. Bakulev, V. A.; Kappe, C. O.; Padwa, A. In Organic Synthesis: Theory and Applications; Hudlicky, T., Ed.; JAI Press: Greenwich, 1996; Vol. 3, pp 149-229.

27. Bakulev, V.A. Russ. Chem. Rev. 1995, 64, 99.

28. Bakulev, V.A.; Biritschowa, N.; Pitchko, V.A. Khim. Geterotsikl. Soedin. 1997, 113.

29. Fabian, W.M.F.; Bakulev, V. A.; Kappe, C. O. J. Org. Chem. 1998, 63, 5801.

30. Fabian, W. M. F.; Kappe, C. O.; Bakulev, V. A. J. Org. Chem. 2000, 65, 47.

31. Jay, R.; Curtius, Th. Ber. 1889, 27, 61. 